\title{
HYBRID K-MEANS DAN PARTICLE SWARM OPTIMIZATION UNTUK CLUSTERING NASABAH KREDIT
}

\author{
Yusuf Priyo Anggodo ${ }^{1}$, Winda Cahyaningrum², Aprilia Nur Fauziyah ${ }^{3}$, Irma Lailatul Khoiriyah ${ }^{4}$, \\ Oktavianis Kartikasari $^{5}$, Imam Cholissodin ${ }^{6}$ \\ ${ }^{123456}$ Fakultas Ilmu Komputer, Universitas Brawijaya, Indonesia \\ Email: ${ }^{1}$ anggodoyusuf1950@gmail.com, ${ }^{2}$ winda.cahyaningrum1@ gmail.com, ${ }^{3} \mathrm{Nfapri17} @$ gmail.com, \\ 4irma.lailatul31@gmail.com, ${ }^{5}$ oktakartikasari5@gmail.com, 6 imamcs@ub.ac.id
}

(Naskah masuk: 20 Februari 2017, diterima untuk diterbitkan: 7 Mei 2017)

\begin{abstract}
Abstrak
Kredit merupakan suatu pendapatan terbesar bagi bank. Akan tetapi, bank harus selektif dalam menentukan nasabah yang dapat menerima kredit. Permasalahan ini menjadi semakin komplek karena ketika bank salah memberikan kredit kepada nasabah dapat merugikan, selian itu banyaknya parameter penentu dalam penentuan nasabah yang kredit. Clustering merupakan salah satu cara untuk dapat menyelesaikan permasalahan ini. KMeans merupakan metode yang simpel dan popular dalam menyelesaikan permasalahan clustering. Akan tetapi, K-Means murni tidak dapat memberikan solusi optimum sehingga perlu dilakukan improve untuk mendapatkan solusi optimum. Salah satu metode optimasi yang dapat menyelesaikan permasalahan optimasi dengan baik adalah particle swarm optimization (PSO). PSO sangat membantu dalam proses clustering dengan melakukan optimasi pada titik pusat tiap cluster. Untuk meningkatkan hasil yang lebih baik pada PSO ada beberapa improve yang dilakukan. Pertama penggunaan time variant inertia untuk membuat nilai $w$ atau inertia dinamis tiap iterasinya. Kedua melakukan kontrol kecepatan partikel atau velocity clamping untuk mendapatkan posisi terbaik. Selian itu untuk mengatasi konvergensi dini dilakukan hybrid PSO dengan random injection. Hasil pengujian menunjukan hybrid PSO K-Means memberikan hasil terbesar dibandingkan K-Means dan PSO KMeans, dimana silhouette coefficient dari K-Means, PSO K-Means, dan hybrid PSO K-Means masing-masing $0.57343,0.792045,1$.
\end{abstract}

Kata kunci: Kredit, Clustering, PSO, K-Means, Random Injection

\begin{abstract}
Credit is a biggest revenue for the bank. However, banks have to be selective in deciding which clients can receive the credit. This issue is becoming increa singly complex because when the bank was wrong to give credit to customers can do harm, that the large number of selian deciding parameter in determining customer credit. Clustering is one way to be able to resolve this issue. K-Means is a simple and popular method in solving clustering. However, the K-Means pure can not provide optimum solutions so that needs to be done to get the optimum solution to improve. One method of optimization that can solve the problems of optimization with particle swarm optimization is good (PSO). PSO is very helpful in the process of clustering to perform optimization on the central point of each cluster. To improve better results on PSO there are some that do improve. The first use of time variant inertia to make the value of each dynamic inertial $w$ or iterasinya. Both control the speed of the particle velocity or clamping to get the best position. Selian it to overcome premature convergence do hybrid PSO with random injection. The results of this researchprovide the optimum results for solving clustering of customer credits. The test results showed the hybrid PSO K-Means provide the greatest results than K-Means and PSO K-Means, where the silhouette's of the K-Means, PSO K-Means, and hybrid PSO K-Means respectively 0.57343, 0.792045, 1.
\end{abstract}

Keywords: Credit, Clustering, PSO, K-Means, Random Injection

\section{PENDAHULUAN}

Kredit menurut undang-undang No.10/1998 pasal 1 (11) tentang Perubahan Atas undang-undang No.7/1992 tentang Perbankan merupakan kesepakatan antara pihak penyedia jasa keuangan dengan pihak lain atas pernyediaan uang atau tagihan yang akan dikembalikan sesuai dengan kesepakatan waktu dan bunga yang telah disepakati bersama (YLBHI, 2007). Kredit timbul dari adanya kepercayaan antara pemberi kredit dengan penerima kredit bahwa penerima kredit dapat memenuhi perjanjian atau kesepatakan bersama. Penjaminan keamanan transaksi dilakukan dengan melakukan pemilihan nasabah yang akan melakukan kredit secara selektif. Setiap bank memiliki parameter untuk menentukan nasabah yang dapat memperoleh kredit.

Penentuan pemberian kredit pada nasabah menjadi satu masalah yang cukup kompleks karena disatu sisi kredit dapat memberi masukan bank yang 
cukup besar sedangkan disisi lain dapat merugikan jika nasabah tidak dapat membayar tagihan kredit. Resiko pemberian kredit pada nasabah yang kurang tepat menyebabkan bank tidak memperoleh pendapatan bunga, selain itu jumlah tagihan harus dikompensasi dengan jumlah modal sehingga modal yang ada akan berkurang dan mungkin habis (Suharli dan Oktorina, 2005). Hal tersebut dapat melanggar ketentuan Capital Adequacy Ratio. Jika Bank memiliki modal yang cukup, maka tagihan tersebut akan dicadangkan sesuai dengan peraturan Bank Indonesia No. 7/2/PBI/2005. Hal tersebut berpengaruh terhadap dana yang dapat ditempatkan dan menghasilkan bagi bank (Suhardi, 2006).

Ada berbagai pendeketan untuk menyelesaikan permasalahan tersebut, salah satunya adalah clustering. Ketepatan dalam membentuk model akan memberikan hasil yang maksimal (Anggodo dan Mahmudy, 2016). K-Means merupakan metode clustering yang populer dan bersifat tanpa kendali (Karimov dan Ozbayglu, 2015). Pembentukan model dengan K-Means dari data yang besar dapat memaksimalkan hasil pengelompokan (MacQueen, 1967). Tujuan utama K-Means adalah melakukan clustering objek ke cluster atau kelompok. Pertama adalah menentukan jumlah $k$ yang mempresentasikan jumlah cluster yang akan dibentuk, lalu menentukan titik pusat atau centroid untuk setiap cluster dan dilakukan pengelompokan. Akan tetapi, karena penentuan titik pusat dilakukan secara acak pada tahapan pertama dan mengambil nilai rata-rata untuk langkah selanjutnya memberikan hasil yang kurang maksimal dan diperoleh konvergensi optimum local (Niknma dan Amiri, 2010). Permasalahan tersebut dapat diatasi dengan melakukan optimasi nilai titik pusat sehingga didapatkan titik pusat yang paling maksimal untuk melakukan perhitungan K-Means.

Ada berbagai metode meta-heuristik yang dapat digunakan untuk mengatasi permasalahan optimasi (Anggodo et al, 2017). PSO merupakan salah satu metode yang dapat melakukan optimasi nilai titik pusat K-Means dengan hasil yang baik (Kuo et al, 2011). Penggunaan PSO dapat diterapkan untuk melakukan optimasi nilai titik pusat dengan mempresentasikan solusi permasalahan dalam bilangan real (Alam et al, 2015). PSO terinspiransi dari kecerdasan individu dan social dari burung (Kennedy dan Eberhart, 1995). Pada penelitian Liu et al (2014) penggunaan PSO dapat melakukan clustering segmentasi citra digital. Sedangkan pada permasalahan komplek penggunaan PSO juga sangat membantu dalam melakukan clustering ( $\mathrm{Li}$ et al, 2017; Armano dan Farmani, 2016; Anggodo dan Mahmudy, 2017). Berdasarkan penelitian sebelumnya ditunjukan penggunaan PSO sangat membantu untuk melakukan optimai nilai centroid sehingga didapatkan tingkat kesalahan clustering yang rendah. Penelitian clustering nasabah kredit sebelumnya pernah diajukan oleh Wahyuni et al
(2016) dengan menggunakan hybrid K-Means dan PSO. Akan tetapi, pada penelitan sebelumnya hanya digunakan 2 parameter pada penelitian ini digunakan 13 parameter untuk menentukan seorang nasabah layak menerima kredit atau tidak. Selain itu juga dilakukan penanganan konvergensi dini untuk mendapat solusi terbaik menggunakan random injection (Mahmudy, 2015).

Fokus pertama penelitian ini adalah melakukan clustering nasabah kredit berdasarkan 13 parameter. Kedua untuk mendapatkan hasil clustering yang maksimal dan mencegah kovergensi optimum lokal dilakukan optimasi titik pusat menggunakan PSO. Ketiga pengabungan random injection dan PSO untuk penanganan konvergensi dini dan mendapatkan solusi terbaik.

\section{ANALISIS NASABAH KREDIT}

Kredit merupakan suatu pembiayan yang diberikan bank kepada nasabah untuk jangka pendek (Sheny dan Williams, 2017). Pinjaman yang diberikan untuk keperluan sehari-hari rumah tangga, keperluan membeli rumah, motor, dan lain sebagainya yang bersifat komsumtif. Walaupun kredit bukanlah bantuan likuidats atau kewajiban perusahaan memenuhi kewajiban jangka pendek akan tetapi kredit juga digunakan untuk keperluan produkti. Berdasarkan hal tersebut kredit menjadi sumber pendapatan paling besar bagi bank, disatu sisi juga memiliki resiko yang besar (Suhardi, 2006). Selain itu pada penelitian Albuquerque et al (2015) menunjukan hasil prediksi nasabah kredit dari tahun ketahun semakin meningkat sehingga bank harus selektif dalam mengambil keputusan untuk mendapatkan pendapatan yang besar dan resiko yang kecil. Pada penelitian ini akan digunakan data dari UCI Dataset. Pada penelitian ini akan digunakan 4121 data dengan 13 parameter lain pekerjaan, status, pendidikan, pernah kredit, kredit rumah, pinjaman bank yang merupakan parameter tergolong kategori. Sedangkan pemasaran sebelumnya, umur, rata-rata gaji dalam tiga bulan, indek konsumsi nasabah dalam satu bulan, indek kepercayaan nasabah dalam satu bulan, rata-rata euribor 3 bulan untuk harian, dan nomer perkerja dalam 4 bulan merupakan parameter tergolong numerik. Tabel 1 menunjukan data nasabah kredit

Table 1. Data nasabah kredit

\begin{tabular}{ccccccccccc}
\hline No & $\mathbf{g 1}$ & $\mathbf{g} 2$ & $\mathbf{g}$ & $\mathbf{g}$ & $\mathbf{g}$ & $\mathbf{g}$ & $\mathbf{g}$ & $\mathbf{g}$ & $\ldots$ & $\mathbf{g}$ \\
& & & $\mathbf{3}$ & $\mathbf{4}$ & $\mathbf{5}$ & $\mathbf{6}$ & $\mathbf{7}$ & $\mathbf{8}$ & $\cdots$ & $\mathbf{1 3}$ \\
\hline 1 & 30 & 2 & 2 & 3 & 1 & 2 & 1 & 2 & $\ldots$ & 5099.1 \\
2 & 39 & 8 & 3 & 4 & 1 & 1 & 1 & 2 & $\ldots$ & 5191 \\
- & - & - & - & - & - & - & - & - & $\cdots$ & $\ldots$ \\
- & - & - & - & - & - & - & - & - & $\ldots$ & $\cdots$ \\
- & - & - & - & - & - & - & - & - & $\ldots$ & $\ldots$ \\
2120 & 18 & 0 & 0 & 0 & 0 & 0 & 0 & 1 & $\cdots$ & 4963.6 \\
2121 & 88 & 11 & 3 & 7 & 2 & 2 & 2 & 3 & $\ldots$ & 5228.1 \\
\hline
\end{tabular}

Dimana parameter nasabah kredit menunjukan g1, g2, g3, g4, g5, g6, g7, g8, g9, g10, g11, g12, g13 secara berurut-urut adalah umur, pekerjaan, status, 
pendidikan, pernah kredit, kredit rumah, pinjaman bank, pemasaran sebelumnya, rata-rata gaji dalam tiga bulan, indek konsumsi nasabah dalam satu bulan, indek kepercayaan nasabah dalam satu bulan, rata-rata euribor 3 bulan untuk harian, dan nomer perkerja dalam 4 bulan.

\section{K-MEANS}

Prosedur untuk dalam melakukan clustering K-Means sangatlah simpel dan mendapatkan hasil yang terbaik (MacQueen, 1967). Pertama melakukan insisialisasi nilai $k$ yang merupakan jumlah cluster, lalu menentukan titik pusat untuk tiap cluster secara acak. Setiap objek akan diatur untuk dimasukan ke cluster tertentu, dimana objek-objek dalam satu cluster memiliki kemiripan. Penentuan kemiripan objek dengan titik pusat cluster diukur dengan Euclidiean Distance (D) yang ditunjukan pada persamaan 1. Sebuah objek akan masuk ke cluster yang memiliki nilai $\mathrm{D}$ terkecil.

$$
D\left(x_{2}, x_{1}\right)=\sqrt{\sum_{j=1}^{p}=\left(\mathrm{x}_{2 j}-\mathrm{x}_{1 j}\right)^{2}},
$$

Dimana,

$$
p=\text { Dimensi data }
$$

$x_{1}=$ Posisi titik 1

$x_{2}=$ Posisi titik 2

Tahapan algoritma clustering K-Means sebagai berikut (Karimi dan Guererro-Zapata, 2015):

1. Insialisasi nilai $k$ cluster dan centroid tiap cluster secara acak.

2. Mentukan setiap objek masuk cluster dengan jarak terdekat berdasarkan nilai Euclidiean Distance.

3. Melakukan perhitungan ulang nilai centroid tiap cluster dengan persamaan 2 .

$\mathrm{V}_{j}=\frac{1}{n_{j}} \sum_{p=0}^{n}$ data $_{\mathrm{p}}$,

dimana $\mathrm{V}_{j}$ merupakan nilai centroid dari cluseter $j . \mathrm{n}_{\mathrm{j}}$ merupakan jumlah objek dalam cluser $j$. data $\mathrm{p}_{\mathrm{p}}$ menunjukan vektor data ke $p$.

4. Ulangi langkah ke 2 sampai nilai centroid tidak berubah atau sudah melampau iterasi terntentu.

\section{PARTICLE SWARM OPMITIZATION}

PSO merupakan metode optimasi bersifat stotastik yang merepresentasikan solusi permasalahan dalam bentuk partikel (Kennedy dan Eberhart, 1995). Partikel dibangkitkan secara acak sebanyak $n$ partikel, tiap partikel terdiri dari beberapa dimensi posisi $x_{i}$ dan kecepatan $v_{i}$. Tiap partikel akan diukur seberapa besar nilai fitness yang diberikan dengan persamaan 3 .

$$
F=f(\mathrm{x})
$$

Dimana $f(\mathrm{x})$ adalah nilai dari silhouette coeficient, yaitu suatu metode untuk mengukur objek yang terbentuk dalam cluster. Semakin besar nilai silhouette coefficient maka semakin bagus data yang terkelompokan. Setiap partikel akan "terbang" menjelajahi ruang pencarian solusi. Perpindahan dari satu posisi ke posisi lainnya sangat dipengaruhi oleh kecepatan tiap partikel, untuk mendapatkan posisi terbaik diperlukan formulasi kecepatan yang dinamis menggunakan persamaan 4 (Eberhart dan Shi, 2000).

$$
\mathrm{v}_{\mathrm{i}}^{\mathrm{t}+1}=\mathrm{w} \cdot \mathrm{v}_{\mathrm{i}}^{\mathrm{t}}+\mathrm{c}_{1} \cdot \mathrm{r}_{1} \cdot\left(\mathrm{p}_{\mathrm{i}}-\mathrm{x}_{\mathrm{i}}\right)+\mathrm{c}_{2} \cdot \mathrm{r}_{2} \cdot\left(\mathrm{pg}_{\mathrm{i}}-\mathrm{x}_{\mathrm{i}}\right),
$$

dimana $v_{i}$ menunjukan nilai kecepatan untuk dimensi partikel ke $i$ sampai ke $n$, t menunjukan waktu iterasi, w merupakan nilai vektor inertia yang nilainya didapatkan secara dinamis menggunakan persamaan 5 (Ratnaweera et al, 2004). $p_{i}$ adalah posisi terbaik yang pernah didapatkan untuk tiap partikel, sedangkan $p g_{i}$ adalah posisi terbaik yang pernah dicapai oleh keseluruhan partikel. $c_{1}$ dan $c_{2}$ berurut adalah konsanta cognitive dan social, yang mana pada penelitian ini bernilai 1. $r_{1}$ dan $r_{2}$ adalah bilangan yang dibangkitkan secara acak antara $[0,1]$. Setelah didapatkan kecepatan maka akan dilakukan update posisi menggunakan persamaan 6 .

$$
\begin{aligned}
& w=\left(w_{\max }-w_{\min }\right) \frac{(\text { Iterasi }-t)}{\text { Iteras } i}+\mathrm{w}_{\min }, \\
& x_{i}^{t+1}=x_{i}+v_{i}^{t+1}
\end{aligned}
$$

Pada perpindahan posisi partikel PSO biasanya terlalu cepat sehingga tidak dapat menemukan solusi optimum. Hal tersebut dapat diatasi dengan melakukan kontrol kecepatapan atau velocity clamping (Marini dan Walzcak, 2015). Mekanisme kontrol kecepatan dengan melakukan kondisi untuk kecepatan tiap partikel menggunakan persamaan 7 .

$$
\begin{aligned}
& \text { if }\left(v_{i j}{ }^{t+1}>v_{j}{ }^{\text {max }}\right) \text { maka } v_{i j}{ }^{t+1}=v_{j}{ }^{\text {max }} \\
& \text { if }\left(v_{i j}{ }^{t+1}<v_{j}{ }^{\text {min }}\right) \text { maka } v_{i j}{ }^{t+1}=v_{j}{ }^{\text {min }},
\end{aligned}
$$

sedangkan nilai $\mathrm{v}_{\mathrm{j}}{ }^{\text {max }}$ dibangkitan menggunakan persamaan 8 dan $\mathrm{v}_{\mathrm{j}}^{\mathrm{min}}$ merupakan nilai negatif dari $\mathrm{v}_{\mathrm{j}}^{\max }$.

$$
\mathrm{v}_{\mathrm{j}}^{\max }=k \frac{\left(x_{j, \max }-x_{j, \min }\right)}{2}, k \varepsilon(0,1],
$$

Siklus perhitungan nilai kecepatan $\mathrm{v}_{\mathrm{i}}$ dan update posisi $\mathrm{x}_{\mathrm{i}}$ akan terus diulangai sampai iterasi selesai. Ketika iterasi sudah selesai, partikel terbaik keluar sebagai solusi optimum.

\section{RANDOM INJECTION}

Random injection merupakan suatu metode yang digunakan untuk penangan konvergensi dini. Random injection pertama diajukan untuk menangani permasalahan konvergensi dini pada algoritma genetika (Mahmudy et al, 2013).

Permasalahan yang sering terjadi pada PSO adalah ketika iterasi tertentu, nilai solusi yang diberikan tiap partikel sama sebelum tercapai solusi optimum. Pada penelitian Wahyuni et al (2016) 
penggunaan hybrid PSO masih belum memberikan hasil yang solusi optimum karena belum dilakukan penanganan konvergensi dini. Berbagai macam penanganan konvergensi dini salah satunya random injection, pada penelitian Mahmudy (2015) penggunaan random injection dapat meningkatkan hasil akurasi dari pada penggunaan PSO saja. Makanisme randon injection sangat sederhana, dengan memasukan $p$ partikel acak pada $q$ iterasi. Penentuan nilai $p$ partakel dan $q$ iterasi yang terbaik harus dilakukan pengujian terlebih dahulu.

\section{SILHOUETTE COEFFICIENT}

Silhouette coefficient merupakan suatu metode yang digunakan untuk mengukur seberapa baik objek diletakan dalam cluster (Wahyuni et al, 2016). Metode ini merupakan penggabungan dari metode cohesion dan separation (Anggara et al, 2016) yang digunakan untuk melakukan perhitungan nilai fitness pada tiap partikel dalam PSO. Tahapan perhitungan silhouette coefficient ditunjukan pada persamaan 9 sampai 12:

1. hitung jarak rata-rata $i$ titik centroid ke semua objek dalam satu cluster.

$\alpha(i)=\frac{1}{|\mathrm{~A}|} \sum j \in_{A, j \neq i} C d(i, j)$,

Dimana $j$ merupakan objek dalam cluster $A$ dan $d(i, j)$ merupakan jarak objek $i$ ke $j$.

2. hitung jarak rata-rata $i$ titik centroid ke semua objek cluster lain, lalu ambil nilai terkecil.

$d(i, C)=\frac{1}{|\mathrm{~A}|} \sum j \in C d(i, j)$,

3. Dimana $d(i, C)$ merupakan jarak objek $i$ ke objek cluster lain.

$b(i)=\min C \neq A d(i, C)$,

4. hitung nilai silhouette coefficient untuk tiap centroid.

$$
s(i)=\frac{\mathrm{b}(\mathrm{i})-\mathrm{a}(\mathrm{i})}{\max (\mathrm{a}(\mathrm{i}), \mathrm{b}(\mathrm{i}))},
$$

Nilai rata-rata silhouette coefficient atau $s(i)$ menunjukan seberapa tepat data dikelompokan,

\section{HYBRID PSO K-MEANS}

Siklus Hybrid PSO K-Means Clustering

Langkah 1: inisialisasi

- Inisialisasi parameter PSO seperti $n, w_{\max }$, $w_{\text {min }}, c_{1}, c_{2}$.

- inisialisasi partikel yang merepresentasikan nilai centroid tiap cluster dan kecepatan.

Langkah 2: update

- update posisi tiap partikel dan hitung nilai fitnessnya menggunakan K-Means

- Update posisi terbaik untuk tiap partikel.

- Update posisi terbaik keseluruhan partikel.

Langkah 3: random injection

- Memasukan $p$ partikel yang dibangkitkan secara acak untuk tiap $q$ iterasi.

Langkah 4: kondisi berhenti

- Jika iterasi belum selesai lakukan langkah 2 dan sudah berhenti.

Gambar 1. Siklus metode hybrid PSO K-Means

Gambar 1 menunjukan siklus metode hybrid PSO K-Means dalam melakukan clustering data nasabah kredit. Salah satu hal yang cukup berpengaruh terhadap hasil clustering adalah representasi partikel PSO dalam melakukan optimasi nilai centroid. Penelitian ini representasi partikel dalam bentuk kategori numerik dan interger sesuai dengan batasan masing-masing parameter. Terdapat dua baris dan 13 kolom, dimana baris merupakan nilai centroid tiap cluster dan kolom merupakan dimensi partikel yang merepresentasikan nilai dari parameter yang ditunjukan pada Tabel 2 dan Gambar 2 menunjukan alur kerja sistem.

Table 2. Representasi partikel

\begin{tabular}{ccccccccccc}
\hline $\mathbf{g 1}$ & $\mathbf{g 2}$ & $\mathbf{g}$ & $\mathbf{g}$ & $\mathbf{g}$ & $\mathbf{g}$ & $\mathbf{g}$ & $\mathbf{g}$ & $\mathbf{g 9}$ & $\ldots$ & $\mathbf{g}$ \\
& & $\mathbf{3}$ & $\mathbf{4}$ & $\mathbf{5}$ & $\mathbf{6}$ & $\mathbf{7}$ & $\mathbf{8}$ & $\mathbf{1 3}$ & \\
\hline 35 & 7 & 0 & 1 & 1 & 0 & 1 & 2 & 0.9 & $\ldots$ & 4335.7 \\
47 & 8 & 0 & 4 & 0 & 1 & 1 & 2 & -1.2 & $\ldots$ & 3049.9 \\
\hline
\end{tabular}

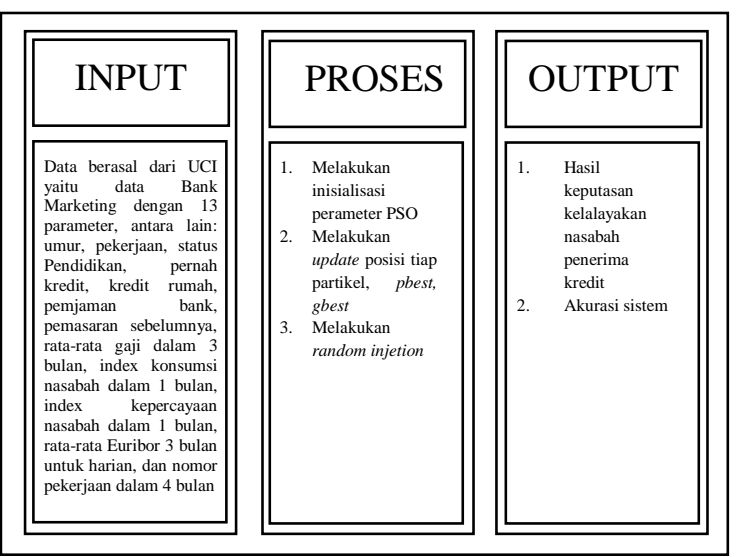

Gambar 2. Alur kerja sistem

\section{METODOLOGI}

Proses pengelompokan nasabah kredit berdasarkan 13 parameter pada penelitian ini, akan dimaksimalkan menggunakan metode hybrid PSO K-Means. Langkah pertama K-Means adalah membangkitkan titik pusat secara acak. Pada penelitian ini terdapat 2, yaitu "diterima" untuk 1 dan "ditolak" untuk 2. Tabel 3 menunjukan titik pusat dari 2 klas.

Table 3. Representasi partikel

\begin{tabular}{cccccccccccc}
\hline No & $\mathbf{g 1}$ & $\mathbf{g 2}$ & $\mathbf{g}$ & $\mathbf{g}$ & $\mathbf{g}$ & $\mathbf{g}$ & $\mathbf{g}$ & $\mathbf{g}$ & $\mathbf{g 9}$ & $\ldots$ & $\mathbf{g}$ \\
& & & $\mathbf{3}$ & $\mathbf{4}$ & $\mathbf{5}$ & $\mathbf{6}$ & $\mathbf{7}$ & $\mathbf{8}$ & $\mathbf{1 3}$ \\
\hline 1 & 35 & 7 & 0 & 1 & 1 & 0 & 1 & 2 & 0.9 & $\ldots$ & 4335.7 \\
2 & 47 & 8 & 0 & 4 & 0 & 1 & 1 & 2 & -1.2 & $\ldots$ & 3049.9 \\
\hline
\end{tabular}

Langkah selanjutnya adalah menghitung kedekatan setiap dengan centroid 1 dan 2 . Semisal terdapat 
data $(30,5,1,2,1,1,1,0,0.5,40,-15,1.2,3555)$, sehingga diperoleh jarak dengan kedua centroid menggunakan persamaan 1 .

$$
\begin{aligned}
& D\left(\text { data, } c_{1}\right)= \begin{array}{c}
(35-30)^{2}+(7-5)^{2}+(0-1)^{2} \\
+(1-2)^{2}+(1-1)^{2}+(0-1)^{2} \\
+(1-1)^{2}+(2-0)^{2}+(0.9-0.5)^{2} \\
+(16 . .428-40)^{2}+(-27.2+15)^{2} \\
+(1.367-1.2)^{2}+(4335.7-3555)^{2}
\end{array} \\
& D\left(\text { data, } c_{1}\right)=780.1748
\end{aligned}
$$

Dengan cara yang sama sehingga diperoleh nilai $D\left(\right.$ data, $\left.\mathrm{c}_{2}\right)=507.4336$. Karena jarak ke centroid 2 lebih pendek maka data tersebut dimasukan ke dalam cluster 2. Langkah selanjutnya adalah melakukan penentuan cluster untuk data lainnya, lalu dilakukan perhitungan titik pusat menggunakan persamaan 2 sampai nilai titip pusat tidak berubah atau iterasi berahkir.

Pada PSO proses pertama adalah pembangkitan nilai partikel secara acak sesuai dengan batasan masing dimensi dalam partikel. Tabel 4 menunjukan hasil pembangkitan nilai partikel. Selain itu inisialisai nilai kecepatan tiap dimensi pada partikel dengan nilai 0 .

Table 4. Inisialisasi partikel awal

\begin{tabular}{cccccccccccc}
\hline \multirow{2}{*}{ No. } & $\mathbf{g 1}$ & $\mathbf{g 2}$ & $\mathbf{g}$ & $\mathbf{g}$ & $\mathbf{g}$ & $\mathbf{g}$ & $\mathbf{g}$ & $\mathbf{g}$ & $\mathbf{g 9}$ & $\ldots$ & $\mathbf{g}$ \\
\hline 1 & 35 & 7 & 0 & 1 & 1 & 0 & 1 & 2 & 0.9 & $\ldots$ & 4335.7 \\
& 47 & 8 & 0 & 4 & 0 & 1 & 1 & 2 & -1.2 & $\ldots$ & 3049.9 \\
2 & 25 & 5 & 1 & 3 & 0 & 0 & 1 & 1 & 0.5 & $\ldots$ & 2000.7 \\
& 45 & 3 & 0 & 2 & 1 & 1 & 1 & 0 & 1 & $\ldots$ & 5000.9 \\
- & - & - & - & - & - & - & - & - & - & - & - \\
- & - & - & - & - & - & - & - & - & - & - & - \\
20 & 34 & 5 & 0 & 2 & 1 & 0 & 1 & 1 & -0.5 & $\ldots$ & 5000.7 \\
& 50 & 8 & 0 & 1 & 0 & 0 & 0 & 1 & 0.4 & $\ldots$ & 3000.9 \\
\hline
\end{tabular}

Beberapa parameter yang dilakukan inisalisasi diawal seperti jumlah partikel, jumlah iterasi, cognitif, $w_{\max }$, dan $w_{\min }$. Langkah selanjutnya adalah menghitung nilai fitness dari setiap partikel, dimana nilai fitness diperoleh dari silhouette coefficient pada persamaan 9-12. Tabel 5 menunjukan hasil perhitungan fitness untuk setiap partikel.

Table 5. Hasil perhitungan nilai fitness

\begin{tabular}{cc}
\hline Partikel & Fitness \\
\hline 1 & 0.2345 \\
2 & 0.3214 \\
$\ldots$ & $\ldots$ \\
20 & 0.1414 \\
\hline
\end{tabular}

Setelah didapatkan nilai fitness untuk tiap partikel maka dilakukan upload pbest dan gbest yaitu nilai fitness terbaik pada tiap partikel dan keseluruhan partikel. Selanjutnya adalah tahapan melakukan perubahan kecepatan untuk tiap dimensi pada partikel menggunakan persamaan 4. Akan tetapi, bangkitkan terlebih dahulu nilai $w$ menggunakan perasamaan 5 dengan nilai iterasi $4, c_{1}=1, c_{2}=1, r_{1}$ $=1$, dan $r_{2}=1$.

$$
w=(0.9-0.4) \frac{(10-1)}{10}+0.4=0.96
$$

$\mathrm{v}_{2,1}{ }^{2}=0.96 \cdot 0+1.1 .(25-30)+1.1 \cdot(25-30)=-10$

Pada partikel 2 dimensi 1 diperoleh nilai kecepatan 10, dengan cara yang sama maka diperoleh kecepatan pada dimensi tiap partikel yang ditunjukan pada Tabel 6.

Table 6. Kecepatan baru

\begin{tabular}{cccccccccccc}
\hline \multirow{2}{*}{ No. } & $\mathbf{g 1}$ & $\mathbf{g 2}$ & $\mathbf{g}$ & $\mathbf{g}$ & $\mathbf{g}$ & $\mathbf{g}$ & $\mathbf{g}$ & $\mathbf{g}$ & $\mathbf{2} 9$ & $\mathbf{3}$ & $\mathbf{g}$ \\
& & $\mathbf{3}$ & $\mathbf{4}$ & $\mathbf{5}$ & $\mathbf{6}$ & $\mathbf{7}$ & $\mathbf{8}$ & & $\mathbf{1 3}$ \\
\hline 1 & -10 & 2 & 1 & 0 & 0 & 0 & 1 & 1 & 0.3 & $\ldots$ & 435 \\
& 12 & 3 & 1 & 2 & 0 & 1 & 1 & 2 & 0.5 & $\ldots$ & 304 \\
2 & 14 & 4 & 0 & 1 & 1 & 0 & 1 & 0 & 0.7 & $\cdots$ & 207 \\
& 20 & 4 & 0 & 1 & 0 & 1 & 1 & 0 & 0.8 & $\ldots$ & 500 \\
- & - & - & - & - & - & - & - & - & - & - & - \\
- & - & - & - & - & - & - & - & - & - & - & - \\
20 & 10 & 2 & 0 & 1 & 1 & 0 & 1 & 1 & 0.2 & $\ldots$ & 500 \\
& 23 & 3 & 0 & 1 & 1 & 0 & 0 & 1 & 0.4 & $\ldots$ & 300 \\
\hline
\end{tabular}

Setelah didapatkan kecepatan maka langsung adalah melakukan perubahan posisi mengunakan persamaan 6 .

$$
x_{21}^{2}=25+14=39 .
$$

\begin{tabular}{|c|c|c|c|c|c|c|c|c|c|c|c|}
\hline No. & g1 & g2 & $\begin{array}{l}\mathbf{g} \\
\mathbf{3} \\
\end{array}$ & $\begin{array}{l}\mathrm{g} \\
\mathbf{4} \\
\end{array}$ & $\begin{array}{l}\mathrm{g} \\
5 \\
\end{array}$ & $\begin{array}{l}\mathrm{g} \\
6 \\
\end{array}$ & $\begin{array}{l}\mathrm{g} \\
7 \\
\end{array}$ & $\begin{array}{l}\mathrm{g} \\
\mathbf{8} \\
\end{array}$ & g9 & $\cdots$ & $\begin{array}{c}\mathbf{g} \\
13\end{array}$ \\
\hline \multirow[t]{2}{*}{1} & 25 & 9 & 1 & 1 & 1 & 0 & 2 & 3 & 1.2 & $\ldots$ & $\begin{array}{l}477 \\
0.7\end{array}$ \\
\hline & 59 & 11 & 1 & 6 & 0 & 2 & 2 & 4 & -0.7 & $\ldots$ & $\begin{array}{r}335 \\
3.9\end{array}$ \\
\hline \multirow[t]{2}{*}{2} & 39 & 9 & 1 & 4 & 1 & 0 & 2 & 1 & 1.2 & $\ldots$ & $\begin{array}{l}220 \\
7.7\end{array}$ \\
\hline & 65 & 7 & 0 & 3 & 1 & 2 & 2 & 0 & 1.8 & $\ldots$ & $\begin{array}{l}550 \\
0.9\end{array}$ \\
\hline- & - & - & - & - & - & - & - & - & - & - & - \\
\hline- & - & - & - & - & - & - & - & - & - & - & - \\
\hline \multirow[t]{2}{*}{20} & 44 & 7 & 0 & 3 & 2 & 0 & 2 & 2 & -0.3 & $\ldots$ & $\begin{array}{l}550 \\
0.7\end{array}$ \\
\hline & 73 & 11 & 0 & 2 & 1 & 0 & 0 & 2 & 0.8 & $\ldots$ & $\begin{array}{l}330 \\
0.9\end{array}$ \\
\hline
\end{tabular}

Dengan cara yang sama maka diperoleh nilai posisi baru yang ditunjukan pada Tabel 7 .

Table 7. Posisi baru

Proses PSO akan terus dijalankan sampai iterasi berahkir, gbest keluar sebagai solusi yang diberikan.

\section{HASIL}

Proses pengujian digunakan untuk mengetahui metode yang menghasilkan solusi terbaik. K-Means dan PSO merupakan metode stotastik atau bersifat random sehingga akan dilakukan simulasi sebanyak 5 kali dan hasil ratarata akurasi dan waktu komputasi akan dibandingkan.

Clustering nasabah bank akan diujikan sebanyak 4121 record nasabah. Data tersebut akan dikelompokan ke cluster 1 ("diterima") atau cluster 2 ("ditolak"). Parameter terbaik PSO yang akan digunakan adalah iterasi $=10$, populasi $=10, \mathrm{v}_{\min }=-$ $0.6, \mathrm{v}_{\max }=0.6, \mathrm{w}_{\max }=0.9, \mathrm{w}_{\min }=0.4$. Sedangkan parameter random injection terbaik adalah $p=0.3, q$ $=2$. Hasil pengujian yang telah didapatkan ditunjukan pada Tabel 8 . 
Table 8. Hasil perbandingan

\begin{tabular}{|c|c|c|}
\hline Algoritma & $\begin{array}{c}\text { Rata-rata } \\
\text { Akurasi }\end{array}$ & $\begin{array}{c}\text { Rata-rata } \\
\text { Waktu } \\
\text { komputasi (s) }\end{array}$ \\
\hline K-Means & 0.57343 & 0.58 \\
\hline PSO K-Means & 0.792045 & 1.55 \\
\hline $\begin{array}{c}\text { Hybrid PSO K- } \\
\text { Means }\end{array}$ & 1.00 & 1.67 \\
\hline
\end{tabular}

Berdasarkan hasil pengujian parameter menunjukan bahwa penggunaan hybrid PSO K-Means memberikan hasil akurasi yang maksimal sehingga metode pada penelitian ini dapat menenetukan cluster nasabah kredit dengan sangat baik.

\section{KESIMPULAN}

Clustering permasalahan nasabah kredit telah diselesaikan secara baik menggunakan hybrid particle swarm optimization K-Means. Serangkaian pengujian menunjukan bahwa penggunaan hybrid PSO K-Means dengan random injection memberikan hasil yang mendekati solusi optimum dan waktu komputasi yang relatif cepat, yaitu kurang dari 2 menit untuk jumlah data yang besar. Hybrid PSO K-Means memberikan hasil solusi yang lebih baik dibandingkan dengan PSO K-Means dan K-Means. Penggunakan hybrid PSO K-Means dapat melakukan clustering data dengan benar sebesar $80 \%$.

Pada penelitian ini pada iterasi ke 10 sudah mengalami konvergensi secara global untuk keseluruhan partikel, hal ini karena sebagain besar parameter merupakan tipe data kategori yang jumlah kategorinya tidak lebih dari 5. Untuk mendapatkan hasil yang lebih baik lagi perlu dilakukan seleksi parameter. Salah satu cara seleksi parameter dengan merepresentasikan seleksi parameter kedalam segmen baru dalam partikel PSO (Novitasari et al, 2016).

\section{DAFTAR PUSTAKA}

ANGGODO, Y. P. \& MAHMUDY, W. F., 2016. Peramalan butuhan hidup minimum menggunakan automatic clustering dan fuzzy logical relationship. Jurnal Teknologi Informasi dan Ilmu Komputer (JTIIK), vol. 3, no. 2, pp. 94-102.

ANGGODO, Y. P. \& MAHMUDY, W. F., 2017. Automatic clustering and and optimized fuzzy logical relationships for minimum living needs forecasting. Journal of Environmental Engineering and Sustainable Technology (JEEST), vol. 4, no. 1, pp. 1-7.

ANGGODO, Y. P., ARIYANI, A. K., ARDI, M. K., \& MAHMUDY, W. F. 2017. Optimization of Multi-Trip Vehicle Routing Problem with Time Windows using Genetic
Algorithm. Journal of Environmental Engineering and Sustainable Technology vol. 3, no.2, pp. 92-97.

ANGGARA, M., SUJIANI, H. \& NASUTION, H., 2016. Pemilihan Distance Measure Pada KMeans Clustering Untuk Pengelompokkan Member Di Alvaro Fitness, Jurnal Sistem dan Teknologi Informasi (JustIN), vol. 1, no. 1, pp. 1-6.

ALAM, S., DOBBIE, G. \& REHMAN, S, S., 2015. Analysis of particle swarm optimization based hierarchical data clustering approaches, Swarm and Evolutionary Computation, vol. 25, pp. 36-51.

ARMANO, G. \& FARMANI, M. R., 2016. Multiobjective clustering analysis using particle swarm optimization. Expert Systems With Applications, vol. 55, pp. 184-193

EBERHART, R.C. \& SHI, Y., 2000. Comparing inertia weight and constriction factors in particle swarm optimization. IEEE Congress on Evolutionary Computation, 16-19 Juni, San Diego, CA, US.

KARAMI, A. \& GUERRERO-ZAPATA, M., 2015. A fuzzy anomaly detection system based on hybrid PSO-Kmeans algorithm in contentcentric networks. Neurocomputing, vol. 149, no. PC, pp. 1253-1269,

KARIMOV， J. \& OZBAYOGLU, M., 2015. Clustering Quality Improvement of k-means Using a Hybrid Evolutionary Model, Procedia Comput. Sci., vol. 61, pp. 38-45.

KENNEDY, J. \& EBERHART, R., 1995. Particle swarm optimization. IEEE International Conference on Neural Networks, 27 Nov. 1 Dec., Perth, Western, Australia, vol. 4, pp. 1942-1948.

KUO, R, J., WANG, M, J. \& HUANG, T. W., 2011. An application of particle swarm optimization algorithm to clustering analysis. Soft Comput., vol. 15, no. 3, pp. 533-542.

LIU, L., JIAO, L., ZHAO, J., SHANG, R. \& GONG, M., 2017. Quantum-behaved dicrete multiobjective particle swarm optimization for complex network clustering. Pattern Recognition, vol. 63, pp. 1-14.

LIU, R., CHEN, Y., JIAO, LICHENG. \& LI, Y., 2014. A particle swarm optimization based simultaneous learning framework for clustering and clustering. Pattern Recognition, vol. 47, pp. 2143-2152.

MACQUEEN, J., 1967. Some methods for clustering and analysis of 
multiobservations. Proceedings of the fifth sysposium on mathematical statistic and probability, 21 Juni - 18 Juli, California, USA, vol. 1, pp. 281-297.

MAHMUDY, W. F., 2015. Improved particle swarm optimization untuk menyelesaikan permaslahan part type selection dan mechine loading pada flexible manufacturing system (FMS). Konf. Nas. Sist. Inf. (KNSI), Universitas Klabat, Airmadidi, Minahasa Utara, Sulawesi Utara, 26-28 Februari, pp. 1003-1008.

MAHMUDY, W. F., MARIAN, R. M. \& LUONG, L. H. S. 2013. Optimization of part type selection and loading problem with alternative production plans in flexible manufacturing system using hybrid genetic algorithms - Part 1: modelling and representation. 5 th International Conference on Knowledge and Smart Technology (KST), Chonburi, Thailand, pp. 75-80.

MARINI, F. DAN WALCZAK, B., 2015., Particle swarm optimization (PSO). A tutorial. Chemometrics and Intelligent Laboratory Systems, vol. 149, pp. 153-165.

NIKNAM, T. \& AMIRI, B., 2010. An efficient hybrid approach based on PSO, ACO, and K-Means for cluster analysis. Applied soft computing, vol. 10, pp. 183-197.

NOVITASARI, D., CHOLISSODIN, I. \& MAHMUDY, W. F., 2016. Hybridizing PSO with SA for optimizing SVR applied to software effort estimation. TELKOMNIKA, vol. 14, no. 1, pp. 245-253.

SHENOY, J. \& WILLIAMS, R., 2017. Trade credit and the joint effect of supplier and customer financial characteristics. J. Finan. Intermediation, vol. 29, pp. 68-80.

SUHARLI, M. \& OKTORINA, M., 2005. Memprediksi tingkat pengembalian investasi pada equity securities melalui rasio profitabilitas, likuiditas, dan utang pada perusahaan publik di Jakarta. Semen. Nas. Akunt. VII, pp. 288-296.

RATNAWEERA, A., HALGAMUGE, S. K. DAN WATSON, H. C., 2004. Self-organizing hierarchical particle swarm optimization with time-varying acceleration coefficients, IEEE Transactions on Evolutionory Computation, vol. 8, no. 3, pp. 240-255.

SUHARDI, G., 2006. Resiko dalam pemberian kredit perbankan. Jurnal Hukum Projustitia, vol. 24, no. 1, pp. 96-111.
WAHYUNI, I., AULIYA, Y. A., RAHMI, A. \& MAHMUDY, W. F., 2016. Clustering nasabah bank berdasarkan tingkat likuiditas menggunakan hybrid particle swarm optimization. Jurnal Ilmiah Teknologi dan Informasi ASIA (JITIKA), vol. 10, no. 2, pp. 24-33.

YLBHI, 2007. Panduan Bantuan Hukum di Indonesia: Pedoman Anda Memahami dan Menyelesaikan Masalah Hukum. Jakarta: Yayasan Obor Indonesia. https://books.google.co.id/books?id=Ylogh ffVI2cC. 